\title{
JULIUSZ DOMAŃSKI
}

(Warszawa)

\section{OBECNOŚĆ NIEOBECNEGO*}

Moje relacje z filozofią XVII wieku są żałośnie ubogie, a nic w tym ubóstwie nie kwalifikuje mnie jako jej badacza. Cokolwiek miałem z nią wspólnego, były to albo amatorskie lektury bezinteresowne, albo prace usługowe, mianowicie garść przekładów drobnych pism łacińskich Leibniza i parę usług recenzyjnych, do których - podobnie jak do przekładów - upoważniały mnie głównie moje filologiczne kwalifikacje latynisty. Również ta moja wypowiedź - gościa, któremu uczyniono zaszczyt, zapraszając go na tę konferencję - będzie wypowiedzią amatora i autsajdera.

W ostatnich latach myślałem trochę i pisałem trochę - w trybie właściwym nie tyle historykowi filozofii, ile filologowi-starożytnikowi i filologowi-neolatyniście - o losach spadku po starożytności od średniowiecza do naszych czasów. Próbowałem rozeznać te losy, stosując dwie denominacje, dwa pojęcia: użytkowników dziedzictwa antycznego i badaczy dziedzictwa antycznego. Tych pojęć nie dzieli wyraźna granica, tym bardziej nie dadzą się one traktować jako przeciwstawne. Użytkowanie implikuje uprzedniość jakiegoś poznania, poznanie jako wynik badania u swych początków co najmniej dopuszcza i czyni możliwymi nadzieje na atrakcyjność i pożytek tego, co warto badać ze względu na jego taką czy inną aksjologiczną atrakcyjność. Ostatecznie te dwa pojęcia i te dwie kategorie nazewnicze nie dadzą się ani zredukować do jednego wspólnego pojęcia nadrzęd-

\footnotetext{
* Jest to wystąpienie skierowane do uczestników XI Ogólnopolskiej Konferencji Naukowej: Filozofia XVII wieku - jej źródta i kontynuacje (Białystok, 16-17 czerwca 2015 r.), której prof. dr hab. Juliusz Domański był gościem honorowym (przyp. red.).
} 
nego, ani radykalnie rozdzielić, także wtedy, kiedy spróbujemy przyjrzeć się im w bardziej z natury swej konkretnych procesach historycznych. Łatwo, owszem, skonstatujemy wtedy, że postawa użytkownicza wobec dziedzictwa antycznego z biegiem czasu słabła i zmniejszała swój zasięg, a postawa badawcza z biegiem czasu zasięg swój i swoją intensywność zwiększała i zyskiwała na sile, niemniej przeto i wtedy również widać, że się nie oddzielają od siebie wyraźnie, że się wzajemnie motywują. I że niełatwo jest wypatrzyć taki moment w dziejach, o którym moglibyśmy powiedzieć, że którejś z nich wyrzeczono się na korzyść drugiej całkowicie.

Średniowiecze zachodnie, łacińskie, żyło spadkiem po starożytności, eksploatując go jako coś trwale obecnego i aktualnego, dostosowując go do swoich aktualnych potrzeb, adaptując i modyfikując, tracąc i uszczuplając dziedzictwo starożytności, lecz też niejako go przymnażając falsyfikatami pisarskimi, a niekiedy też społeczno-instytucjonalnymi, które były równie swojskie jak starożytne autentyki. Średniowieczne renesanse - karoliński i ottoński, a w pewien specyficzny sposób jednak także przedłużenie tego drugiego na przełomie wieków XII i XIII w wielkiej scholastyce uniwersyteckiej, wyróżniające się odzyskaniem dla łacińskiego Zachodu całej spuścizny Arystotelesa - praktykowały podobne czynności użytkownicze, wśród tych czynności jednak, jak skłonny jestem sądzić, dominantą jest milczące uznawanie dziedzictwa antycznego za coś bezczasowego i zarazem, jak już zaznaczyłem, swojskiego, bo już we wcześniejszym etapie użytkowniczej recepcji wyselekcjonowanego i przyswojonego przez chrześcijańskich użytkowników starożytnych. Wielki renesans wieków XIV-XVI zmienił to, nie tylko intensyfikując odzyskiwanie i tym samym przymnażanie zasobów antycznego dziedzictwa przez umyślne, celowe poszukiwania i inne pozyskiwawcze zabiegi, ale też przez istotną modyfikację swojej użytkowniczej wobec niego postawy. W wyniku pierwszego wzbogaciło się ono w zachodniej Europie o duże zasoby nie tylko nieznanych tu od starożytności pisarskich dzieł greckich, ale też o wydobyte z zapomnienia zasoby starożytnego piśmiennictwa łacińskiego; wystarczy przypomnieć zanikły od IX wieku poemat filozoficzny Lukrecjusza czy retoryczne dzieło Kwintyliana. Drugim czynnikiem zmiany była wzmożona przez sam upływ czasu świadomość dystansu czasowego wobec starożytności i wraz z nią rozeznawanie i likwidowanie użytkowniczych jej zniekształceń średniowiecznych, co restytuowało dziedzictwo antyczne w jego postaci autentycznej. Cały ten zespół nowych czynności był niewątpliwie skutkiem potrzeb nie użytkowniczych tylko, lecz przede wszystkim badawczych, one jednak tamtych, użytkowniczych, bynajmniej nie przekreśliły, lecz tylko je zmodyfikowały. Dziedzictwo starożytne pozostało nadal cenną wartością, a oczyszczone $\mathrm{z}$ adaptacyjnych modyfikacji, nabrało jeszcze nowej atrakcyjności i zachęcało, aby je przyswoić jeszcze pełniej i użytkować w sposób doskonalszy, umiejętnie je naśladując, a to znaczy 
współzawodnicząc z nim. Użytkownicy-naśladowcy-współzawodnicy z epoki wielkiego renesansu XIV-XVI wieku tworzyli jakby na nowo drugi świat antyczny i własny zarazem. Wyrażali go przede wszystkim w piśmiennictwie łacińskim, ale ten sam świat antyczny chętnie odtwarzali też w rozwijających się szybko językach narodowych.

Postawa użytkownicza wobec dziedzictwa antycznego pozostała więc wspólną cechą średniowiecza i wielkiego renesansu XIV-XVI wieku, choć nie była to już postawa ta sama. Czy przetrwała wielki renesans i była udziałem również epoki, którą czasem nazywamy wczesną nowożytnością (die frühe Neuzeit) i której wyodrębnienie z pewnością jest zasadne? Odpowiem od razu: tak, lecz przetrwała jako postawa znowu swoiście zmodyfikowana, i to tak mocno, że to zmodyfikowanie wolno uznać za graniczne. Opiszę je inaczej, niż to tu uczyniłem z obu postantycznymi epokami wcześniejszymi. Posłużę się mianowicie pomocą cudzą.

W dość leciwej już książce Antiqui und Moderni im Mittelater, którą przed blisko czterdziestu laty recenzowałem w „Studiach Mediewistycznych”, Elisabeth Gössmann, żyjąca dziś jeszcze emerytowana profesor teologii, ściślej: historii teologii średniowiecznej, posługując się innymi niż moje, ale nietrudnymi do spożytkowania równiė̇ w mojej refleksji, średniowiecznymi kategoriami „dawności” i „nowości/tego czesności” (antiquitas i modernitas), za przełomowy fakt wyznaczający zmianę wcześniejszego paradygmatu metanaukowego uznała „reakcję przeciwko tradycjonalizmowi humanistów" - mianowicie renesansowych, tj. wielkiego renesansu XIV-XVI wieku - ze strony późnorenesansowych filozofów przyrody. Już zresztą i przywiązani do antycznego piśmiennictwa humaniści protestowali czasem przeciwko temu przywiązaniu. Ale prawdziwie skuteczna reakcja przeciwko niemu wyszła od późnorenesansowych filozofów przyrody i przyrodników. Oto Galileusz pisze do Keplera: „Ludzie myślą, że filozofia to taka książka jak Eneida lub Odysea i że prawdy szukać należy nie w świecie czy w naturze, lecz [...] w porównywaniu tekstów". Ten zarzut przeciwko uwięzieniu w zapisanej przeszłości, znany zresztą do dziś dość szeroko, wydał pod koniec XVI wieku liczne owoce. Astronomia nova Keplera, De rerum natura iuxta propria principia Telesia (1565), Nova de universis philosophia Patrizziego (1591) - oto zestaw tytułów zapowiadający nowość istotną, nie zaś będącą tylko „odnowieniem" antycznego dziedzictwa, o jakie, modyfikując postawę średniowieczną, upominali się wcześniejsi humaniści, dla których dziedzictwo antyczne było stałym punktem odniesienia, miarą i normą. Przyrodnicy i filozofowie późnego renesansu coraz bardziej odchodzą od antyku, a złoty wiek umieszczają w przyszłości. Tak polaryzuje się poczucie młodości i postępu u przyrodników i mechaników, a związane z kultem antyku poczucie epigoństwa i starzenia się u literatów i artystów. 
Dwa też są w renesansie pojęcia tegoczesności, modernitas. Jedno, humanistyczne, powstające w konfrontacji z antykiem i nie różniące się w sposób istotny od średniowiecznego. Drugie tworzy się drogą swobodnego samostanowienia (freie Selbstsetzung, nazywa to autorka referowanej książki) i, jak się zdaje, bez uwzględnienia - jako drugiego bieguna - starożytności, a tym samym „przygotowuje poczucie nowoczesności dzisiejsze, wedle którego słowo to jest ogólnym, formalnym oznaczeniem tego, co odpowiednie dla danego czasu i co wskazuje na przyszłość". Tak to dosłownie określa autorka.

Nie próbuję niczego dopowiadać do tych moich refleksji i do ułamkowej zaiste relacji z cudzej książki, która niemało się do ich obudzenia niegdyś przyczyniła. Jeżeli w obradach odezwą się jakimś echem, będę się cieszyć, że przynajmniej w taki sposób mogłem skompensować moją w nich fizyczną nieobecność.

W następujących moich publikacjach znaleźć można nieco konkretów ilustrujących powyższe abstrakcyjne ujęcie postaw wobec dziedzictwa antycznego:

Patrystyczne postawy wobec dziedzictwa antycznego $i$ ich nastepstwa $w$ kulturze chrześcijańskiej, w: U progu trzeciego tysiaclecia. Człowiek - nauka wiara, Księga pamiątkowa Sympozjum Naukowego zorganizowanego w Uniwersytecie Warszawskim z okazji 2000-lecia chrześcijaństwa w dniach 19-21 listopada 1999 roku, red. A. Białecka i J. J. Jadacki, Warszawa 2001, s. 39-67.

Dwie glosy do 'Enchiridionu' Erazma z Rotterdamu, w: Studia neolatina. Rozprawy i szkice dedykowane profesor Marii Cytowskiej, red. M. Mejor i B. Milewska-Waźbińska, Warszawa 2003, s. 79-94.

Użytkownicy i badacze filozofii starożytnej $w$ XV wieku, w: Literatura i kultura późnego średniowiecza w Polsce, red. T. Michałowska, Warszawa 1993, s. 29-40.

Les principes de l'usage chrétien du patrimoine classique selon Erasme, w: Education, transmission, rénovation à la Renaissance, textes réunis par B. Pinchard et P. Servet, Genève 2006, s. 213-221.

Użytkownicy $i$ badacze dziedzictwa antycznego czyli o różnicy między humanizmem i humanistyka, w: Nagroda im. Księdza Idziego Radziszewskiego, laudacja: E. I. Zieliński OFMConv, Towarzystwo Naukowe Katolickiego Uniwersytetu Lubelskiego Jana Pawła II, Lublin [2007] (Wykłady i przemówienia, 59), s. 23-32; toż w: J. Domański, Philologica - litteraria - humaniora. Studia i szkice z dziejów recepcji dziedzictwa antycznego, Warszawa 2009, s. 47-52.

Recenzja książki Elisabeth Gössmann Antiqui und Moderni im Mittelater ukazała się (scalona z recenzją innej książki) pod tytułem Trwałość tradycji starożytnej i metamorfozy jej recepcji w świetle dwu niedawnych ksiażek $\mathrm{w}$ „Studiach Mediewistycznych" XIX z. 2, 1978, s. 175-206. 


\section{The Presence of the Absent}

This is the speech, that was addressed to the participants of XI All-Polish Scientific Conference: The Philosophy of XVII century - its Sources and Continuations (Białystok, 16-17 June 2015), of which Professor Juliusz Domański was the guest of honour.

Key words: user of antiquity, inquirer of antiquity

Słowa kluczowe: użytkownik starożytności, badacz starożytności

prof. dr hab. Juliusz Domański, emerytowany profesor Instytutu Filozofii i Socjologii PAN oraz Instytutu Filologii Klasycznej UW 